\title{
COVID-19 and the Sacrificial International Order
}

\author{
Michael Barnett $(0$
}

\begin{abstract}
This essay uses COVID-19 to illuminate the sacrificial practices of the liberal international order as woven through the concepts of humanitarian governance, moral economy, triage, and sacrifice. The concept of a sacrificial international order calls attention to how all international orders have their share of sacrifices-and this includes liberal international orders. International orders can be distinguished by the selection mechanisms used to identify the sacrifices and the meanings attached to them. I call attention to how liberal international orders often rely on markets as a selection mechanism and interpret these deaths as part of progress. Following critical contributions to the study of neoliberalism that show how markets shape the ethics of "giving life" and "letting die," I illuminate these processes through four concepts: humanitarian governance and the claim that the highest moral principle is saving lives and relieving suffering; moral economy that regulates who has access to basic subsistence goods during periods of crisis; triage, which considers how to prioritize whose lives are valued; and whether all deaths count as sacrifices or whether they are better understood as "those who can be killed." I conclude by discussing how COVID-19 conjures hierarchies of humanity ignored by the liberal international order and challenges the discipline to consider the sacrifices in world order.
\end{abstract}

COVID-19 conjures the existence of a sacrificial international order. Jean-Hervé Bradol, a former president of Medecins sans Frontieres (MSF), posed that all international orders produce sacrifices. ${ }^{1}$ He was writing in reaction to the "just wars" of the post-Cold War period, when the international community began using force in defense of humanity. According to the defenders of use of force, violence and collateral damage were unfortunate but necessary and legitimate. The benefits would outweigh the costs: more would live than die from the interventions, and those just wars would help defend a liberal international order and create the conditions for a liberal peace. Progress is never cheap or without its sacrifices. All international orders have sacrifices-including those with the best intentions and visions of humanity.

Editor's note: This article is part of an online supplemental issue on COVID-19 and international relations. The authors were invited by $I O$ 's editorial team and guest editor Michael C. Horowitz. The manuscript was reviewed based on written non-anonymous reviewer comments and during an online workshop. The revised manuscript was evaluated by the $I O$ editorial team. We appreciate the support of Perry World House at the University of Pennsylvania for making this possible.

1. Bradol 2004. 
One way to distinguish between different kinds of international orders is the method of selection and the meaning of the sacrifices. For instance, racialized orders select individuals based on skin color and justify their deaths as necessary for a way of life that benefits the so-called superior race. ${ }^{2}$ Religious orders might select nonbelievers and the blasphemous in the pursuit of purity and the sacred. ${ }^{3}$ Sovereign orders have justified the sacrifice of other states in the name of international order. Poland saw itself as the "Christ of Europe" after it was partitioned out of existence by the great powers for the preservation of the European order in the late eighteenth century. ${ }^{4}$

And what of a liberal international order (LIO) defined by principles of equality, humanity, and progress and sustained by international institutions that promote cooperation, peace, and prosperity? Its axioms interfere with entertaining or even conceiving of the possibility of such sacrifice. Internal critiques acknowledge the LIO's failure to live its principles as well as its unintended consequences, such as an economic globalization that produces winners and losers and translates into widening economic inequality. But the liberal forecast is that in the long run the global spread of rights, democracy, and markets, strengthened by the appropriate institutions, will produce a more prosperous and peaceful world. It is possible. Whether on balance the liberal international order has done more good than harm, or is the worst form of international order except for all the alternatives, are not arguments I can or want to settle here. My point is simpler: the LIO, like all orders, has a sacrificial element.

Liberalism's sacrificial dimension begins with the recognition that while equality is a sacrosanct principle, in practice it has always produced forms of inequality. The same can be said for liberalism's kindred spirit of humanity. Humanity has always been a work in progress, and a central narrative of the history of the enlightenment is the slow, uneven, and incomplete process whereby those who were once considered not quite human become humanized. This hierarchy of humanity translates into the relative value of human lives and the determination of whose suffering matters more than others, the effects of which often work through the market and are especially visible during pandemics. Bradol observed that while people are sacrificed during just wars, more people died from HIV/AIDS than from conflict in 2000 because the afflicted were often stigmatized and treated as less than human, and could not afford antiretroviral drugs. These would-be customers of pharmaceutical companies had neither their humanity nor money. And in the spirit of sacrifice, those companies responded by defending their prices, noting that they needed sufficient profits to motivate them to produce life-saving treatments and vaccines. This is a world, observes the South African writer J.M. Coetzee, that easily reduces people to "another brick in the pyramid of sacrifice." 5 
The relationship between markets and morals is central to scholarship that is critical of neoliberalism and market fundamentalism. ${ }^{6}$ Neoliberalism has two meanings in this argument. There is the neoliberalism associated with the claim that "human well-being can best be advanced by liberating individual entrepreneurial freedoms and skills within an institutional framework characterized by strong private property rights, free markets, and free trade." 7 Where states are accused of having overstepped their boundaries, neoliberalism aims to put them back in their appropriate place in order to let markets function properly. Another meaning of neoliberalism refers to how the market both shapes and constitutes values. Liberalism's claim is that markets work best when walled off from normative concerns such as justice, fairness, and morality. ${ }^{8}$ The liberal mistake is to assume that the market is separate from ethics when it is in fact bound up with them. The market can become an ethic in itself and can eventually replace or diminish previously held ethical beliefs. Markets shape what is valued and what counts as fair, just, or equitable. Markets assign value to living and life, and shape whose suffering counts. While all humans are vulnerable to COVID-19, not all are equally vulnerable and not all have equal access to care. These vulnerabilities are not randomly distributed but rather are patterned by class, race, and other enduring hierarchies that are produced and reproduced by markets.

This essay uses COVID-19 to explore the sacrificial element of the liberal international order. I begin with humanitarian governance and the claim that the highest moral principle is the preservation of life. Compassion and an ethics of care are present in all societies, cultures, and religions, but beginning with the enlightenment and liberalism in eighteenth century Europe they became institutionalized and internationalized into a form of governance that contains a diffuse form of power-biopower- that is directed at "making live and letting die." "Yet the moral principle of preserving life and relieving suffering has been circumscribed and redirected by capitalist expansion and market ideologies. This observation sets up the following three sections: the moral economy, which shapes access to subsistence goods; triage, which concerns the prioritization of treatment during emergencies and situations of scarcity; and sacrifice, which relates to the existing moral order and other categories of dying, including those who can be killed, the abandoned, and the unseen. I conclude by discussing how the concept of sacrifice offers scholars of international relations an alternative way of thinking about both international order and the discipline itself.

Before proceeding, three caveats. Those who study the global politics of living and dying almost always compare the global North and South, showcasing the gross inequalities in life chances between the two. If and when COVID-19 runs its course, the final tally might follow the familiar pattern, particularly as the effects

6. See Harvey 2005; Michéa 2009; Brown 2015; Slobodian 2018; Block and Somers 2014; Fourcade and Healy 2007.

7. Harvey 2005, 2.

8. Adelman 2020, 191.

9. Foucault 2003, 247-48; quoted in Clover 2020. 
include deaths from food insecurity and starvation, the further deterioration of other parts of an already thin health sector, and rising poverty. But for the moment the US and other Western states in the heartland of the liberal order do not have a distinguished record of prevention or containment, and many countries in the global South, such as Vietnam and Rwanda, have put liberal states to shame. This observation has fueled speculation about whether democratic or nondemocratic states are better at plague management, and if so, why. Second, there is considerable variation among Western liberal democracies, which could reflect variations in neoliberalism and market fundamentalism; namely, the more pervasive and intensive the perceived sanctity of the market, the more vulnerable are the weakest members of society. As Maurice Halbwechs writes, there are "good reasons to assume that a society has the mortality rate it deserves and the number of deaths and their distribution among the different age groups faithfully reflects the value that a society attaches to the furtherance of life." ${ }^{10}$ Third, variations also exist in the meaning and practice of liberalism. The sacrificial practices of nineteenth century liberalism are not the same as today's. But the sacrifices remain.

\section{Humanitarian Governance}

Humanitarian governance is "the administration of human collectivities in the name of a higher moral principle that sees the preservation of life and the alleviation of suffering as the highest value of action."11 In the absence of such a principle it would be difficult to explain a nearly unprecedented aspect of the global response to COVID-19: the willingness of many states to bear considerable economic, political, and social costs to save lives and reduce suffering through lockdowns and quarantines. ${ }^{12}$ There is a long and crooked history of the internationalization and institutionalization of humanitarian governance that cannot be surveyed here, but several elements are critical for understanding its existence and limits.

The seeds of humanitarian governance were planted with the enlightenment's emphasis on humanity. Unlike pre-enlightenment thought that contained hierarchies by reason of birthright, connection to God, or some other doctrine, enlightenment ideas of humanity emphasized how all individuals are humans, all humans are equal and capable of reason, and because humans form a common species they are obligated to "treat fellow humans as family." 13 Contributing to these feelings of fellowship were processes of sacralization in which humans became "the object of a sort of religion ... a common faith" and a "religion of humanity." 14 Compassion also became a mark of the human. Compassion exists across all peoples, cultures,

10. Quoted in Hark 2020.

11. Fassin 2007, 151.

12. Fassin 2020a, 3.

13. Wilson and Brown 2009, 43.

14. Cladis 2008, xxviii. 
and religions, but beginning in eighteenth century Europe it became a higher order emotion. The spectacle of misery ceased to generate indifference and instead generated pity and compassion. ${ }^{15}$ Such responses were produced not only by reason and rationality, but also by feelings of sentimentality generated by sad stories. ${ }^{16}$ Suffering incited compassion and feelings of humanity.

Compassion is not enough - it also requires action, and the enlightenment produced a burst of voluntary associations, often organized by religious and humanistic organizations, for the purpose of addressing suffering. Many of these associations evolved from a charity-based model in which giving was motivated by kindness and not obligation, but there was a growing belief that individuals now had duties to others. Negative duties arose, such as avoiding action that produced unnecessary and foreseeable harm, as did positive duties to "prevent and alleviate human suffering," "to protect life and health and to ensure respect for the human being," and to "promote mutual understanding, friendship, co-operation and lasting peace amongst all peoples." 17 And the enlightenment did more than instill a desire to act; it also provided the means to do so. Suffering was no longer something produced by the Gods, nature, or karma. There were humanistic and scientific explanations and solutions. Because of advances in science, technology, social organization, and administration, suffering could be mitigated by human intervention.

Importantly, the ability of states and societies to remove suffering and save lives in a continuous manner depended on administration and governance. Humanitarian governance contains a form of power that Foucault labelled biopower. For Foucault, Europe crossed a "threshold when the biological processes characterizing the life of human beings as a species became a crucial issue for political decision making, a new 'problem' to be addressed by governments" in both exceptional and normal times. ${ }^{18}$ In other words, whereas once the sovereign "took life and let live," now there is "making live and letting die." 19 Biopower is diffused throughout the state apparatus and society; it is a decentralized structure of knowledge involving the state, society, and economy, evident in new fields of sanitation, urban planning, nutrition, social work, and public health. Biopower also changes how the subject defines the self; for instance, creating new self-understandings of responsibility and care of the self, particularly in the areas of hygiene and health. Foucault saw biopolitics, like he did other forms of power, as neither only good or bad but as having the potential for both. For instance, in Discipline and Punish he observes how in the seventeenth century the state responded to the Bubonic Plague by insinuating itself into the "smallest details of everyday life" and with quarantines, multiple separations, methods for delivering food, and new techniques of surveillance and control. ${ }^{20} \mathrm{But}$

15. See Fiering 1976; Sznaider 1998; Arendt 1963, 70-71.

16. Fassin 2011; Festa 2010, 6-7.

17. Pictet 1979.

18. Lorenzini 2020.

19. Foucault 2003, 247-48; quoted in Clover 2020.

20. Foucault 1995, 198. 
methods and techniques designed to improve human life—particularly evident during pandemics such as COVID-19- can become institutionalized and part of systems of control. For instance, contact tracing apps used to contain the spread of COVID-19 can also be used by power-minded governments for tracking society and political opponents. ${ }^{21}$

These practices of humanity that are intended to save life and mitigate suffering have been as uneven as humanity itself. Central to the debate about and expansion of humanity is the question of who is the human..$^{22}$ Distinctions have been made according to race, culture, religion, gender, and other categories of discrimination; liberalism is no exception as it contains status inequalities based on property, gender, and race. In the nineteenth century, liberalism's evolving concept of humanity was shaped by considerations of the physical and cognitive qualities an individual must possess to be counted as a human and of whether all humans are truly equal. Liberals such as John Stuart Mill claimed that there were two kinds of people: those who were fully human (that is, civilized white Westerners) and those who were humans-in-the-making (children in civilized societies and the colonized) because they were still acquiring the necessary rationality and reasoning. Only after World War II did the principle of all humans as equal become widely accepted, but it became diluted in practice as distinctions continued to generate hierarchies of humanity, particularly as they are intertwined with capital and markets. The following sections on the moral economy, triage, and sacrifice are suggestive of how market mechanisms in the liberal order are central to making live and letting die and producing sacrifices that are justified in the name of progress.

\section{Moral Economy}

The concept of the moral economy has many meanings, but I follow the tradition of E.P. Thompson, James Scott, and Karl Polanyi, who highlight whether, when, and how vulnerable populations are helped by others, including the state, through reciprocal expectations to acquire basic subsistence goods during crises. ${ }^{23}$ Charles Tilly's definition works well: when "claimants to a commodity can invoke nonmonetary rights to that commodity ... and third parties will act to support these claims - when, for example community membership supersedes price as a basis of entitlement." 24

Situations like COVID-19 showcase the moral economy when there is unequal access to life-saving medical treatment. During emergencies and situations of widespread hardship, goods are scarce and often priced beyond the reach of vulnerable

21. Global Witness 2020.

22. See Bethencourt 2016; Stuurman 2017.

23. See Thompson 1971 and 1991; Scott 1976; Polanyi 2001. Also see Sandberg 2015; Fassin 2020 b.

24. Quoted in Thompson 1991, 338. 
populations. In many societies, what Scott calls social insurance kicks in at such moments. This insurance is provided by a web of reciprocal obligations among those in the community and is supported by patrimonial relations with political and economic elites and the state..$^{25}$ These are obligations that tap into deeply held beliefs about what is fair and just. However, a moral economy is no utopia; life is often lived on the margins and elites provide aid not because they necessarily care about others but rather because they care about preserving their rule.

Moral economists are particularly attentive to moments when these obligations disintegrate. This can occur for various reasons, but Scott, Thompson, and Polanyi highlight changes in market relations and economic ideologies. Thompson examined the imposition of the corn laws and the end of patrimonial relations between peasants and landowners. From the eighteenth century on, British governments responded to widespread hunger and famine with laissez-faire policies. Although Adam Smith is often cited as something of a bleeding-heart liberal because of his writing on moral sentiments, his heart turned to stone during periods of mass misery. As a fierce advocate of free trade, Smith opposed regulation, including paternalistic protections. He wanted to "demoralize" the market, by which he meant divesting it of intrusive moral imperatives that might interfere with prices and incentives. During the debate over the corn laws in the early 1770s he acknowledged that laissez-faire policies might cause starvation in the short run. But he opposed moral interventions on the grounds that the regulation of corn prices through such measures as a cap on prices would cause speculation and black markets, lead farmers to cut production, retard long-run growth, and increase the risk of future famines. ${ }^{26}$ Scott argued that the introduction of colonialism and the transition to capitalist agriculture in Vietnam and Burma caused landowners to increase their rate of exploitation of increasingly commodified labor and to shred the existing safety net. Polanyi famously proposed the distinction between embedded and disembedded economies. Embedded economies "submerge production and exchange to the purposes and practices of far more significant social, political, or religious institutions." ${ }^{27}$ Disembedded economies, on the other hand, have wrenched the market from social relations and institutions, have an autonomy of their own, and shape what counts as moral, just, and fair. Beyond preventable deaths, what results from the rupture of the moral economy? Thompson documented food riots, Scott protest movements, and Polanyi a "double movement" that created left- and right-wing movements in Europe and the United States.

Markets are global and so, too, are moral economies. Colonial powers often refused to intervene in the market and permitted millions to die as a consequence. In Ireland from 1845 to 1855 about one million Irish died and another two million emigrated in part because Britain's economic ideology and racism led it to elevate 
the market over humanity. This Smithian ideology guided the British colonial authorities' response to a series of food shortages and famines in India. ${ }^{28}$ In 1803-04 the colonial administrators refused to protect food supplies, ban food exports, or provide food subsidies, causing the death of millions. A similar story occurred in 1835, when an estimated 15 to 20 percent of a population of eight million perished. During the Spanish flu perhaps 20 million deaths in western India occurred because the British allowed food exports during a major drought, which led to famine, malnutrition, suppressed immune systems, and widespread flu and pneumonia. ${ }^{29}$

Many of the classic contributions to the scholarship on the modern international political economy include a central concern with the moral economy. Building on Polanyi's The Great Transformation are John Ruggie's arguments about postwar embedded liberalism. ${ }^{30} \mathrm{~A}$ critical lesson of the interwar period is that Western leaders needed to manage the world economy in a way that expanded trade while protecting society from economic downturns. Conversely, the rise of global neoliberalism is credited with helping to dismantle embedded liberalism's moral economy and the obligations of the state for societal welfare during recessions and depressions. ${ }^{31}$ This dismantling required replacing the idea of a society comprised of mutual obligations with a view that it consists of nothing more than voluntary, self-interested exchanges, and that when members fall on hard times they must look to themselves, their neighbor, or charity, and rarely to the government.

How liberalism and neoliberalism have shaped the moral economy has been an important theme in discussions surrounding COVID-19. ${ }^{32}$ There has been considerable commentary on how neoliberalism has eroded the health infrastructure in many liberal economies, a phenomenon made particularly evident by the lack of preparedness of countries that have prided themselves on their health care. Because of the decline of federal funding and the rise of for-profit medicine and insurance companies, US medical facilities have underfunded hospitals, resulting in a severe shortage of beds and 60,000 fewer employees in public health departments today compared to in $2008 .{ }^{33}$ The millions of uninsured and underinsured in the United States also contributes to increasing death rates. In the United Kingdom, the editor of the premier British-based medical journal The Lancet observed that austerity "blunted the ambition and commitment of the government to protect its people," and led to the loss of 17,000 hospital beds and to 40,000 vacant nursing positions. ${ }^{34}$ These trends in advanced liberal economies can be considered self-inflicted because choices were made, but in the global South, international financial institutions-with the backing of the United States and other major Western economies-pushed structural

28. Sharma 2001.

29. Davis 2020b, 8.

30. Ruggie 1982.

31. Davies 2016.

32. Ingram 2020, 92.

33. See Davis 2020b, 10; Davis 2020a.

34. Quoted in Fouskas and Gokay 2020. 
adjustment policies that contributed to a decline in health outcomes for the most vulnerable. ${ }^{35}$

The moral economy focuses on vulnerabilities, recognizes that not all are equally vulnerable, and observes that patterns of vulnerability are often caused by existing economic inequalities and marginalization of particular societal groups. Most discussions of the relationship between the moral economy and vulnerability focus on unequal access to subsistence needs during periods of extremis. But the moral economy also includes the structures that account for why some groups are more likely to have the preconditions that make them vulnerable to disease. ${ }^{36}$ For instance, poverty is often correlated with poor nutrition, toxins in water and the environment, and higher rates of severe stress and mental health challenges. And some racial and minority groups are more likely to live impoverished lives than the rest of society because of a history of exclusion and marginalization, which means that they are more likely to have poor health and less likely to get treatment. This pattern exists in COVID-19. Many news accounts report on how the combination of poverty and other environmental factors explain the higher rates of COVID-19 among minority populations in the United States, and that when members of those populations are infected, they are less likely to receive a high quality of care.

Preconditions are not only produced nationally but also globally. Colonialism and imperialism created unequal exchanges between the core and the periphery-patterns that continued after decolonization and produced enduring vulnerabilities to developments in the core and the global economy in much of the global South. Westernsponsored neoliberal policies are among such pressures, and are associated with growing health inequalities between the global West and South and a decline in health outcomes among marginalized population. The South's vulnerabilities owe not only to its own incapacities but also to its incapacitation. ${ }^{37}$

The market also shapes whose suffering and mortality matters because of its influence on which drugs are produced and who has access to them. Large, profit-oriented pharmaceutical companies play a central role in deciding which diseases get attention, and they prioritize not the diseases that do the most harm but rather those that generate the greatest profits. Accordingly, companies prioritize research and development that target Western consumers, and neglect infectious and noninfectious diseases that primarily affect impoverished populations in the global South. ${ }^{38}$ The satirical newspaper The Onion nailed this feature with the following headline: "Experts: Ebola Vaccine at Least 50 White People Away." 39 Additionally, once vaccines and treatments are brought to market, they are often unaffordable for the poor and most in the global South. In response, various coalitions have formed access to

35. See Ruckert and Lebonté 2013; Rowden 2009.

36. See Farmer 2004; Galtung 1969; Kleinman, Das, and Lock 1997.

37. See Rowden 2009; Schrecker 2020.

38. See Ingram 2020, 91; Trouiller et al. 2002.

39. "Experts: Ebola Vaccine at Least 50 White People Away," The Onion, 30 July 2014, retrieved from $<$ https://www.theonion.com/experts-ebola-vaccine-at-least-50-white-people-away-1819576750>. 
medicine campaigns to negotiate with pharmaceutical companies for lower prices and the production of generics. ${ }^{40}$ The question of access is becoming increasingly urgent as global publics anticipate a vaccine for COVID-19. There are global efforts to provide equitable access, but, so far, they are no match for "vaccine nationalism;" the primary drug-producing countries, China, Western states, and India, have gone to the head of the line and the global South to the back, which brings us to the concept of triage. ${ }^{41}$

\section{Triage}

The word "triage" originated sometime in the fourteenth century from the French word triere, meaning to select, choose, organize, prioritize, or arrange according to the quality of a traded product, such as coffee beans or pelts. Contemporary meanings refer to sorting and prioritizing in situations of scarcity, and especially during medical emergencies. But ordering along what criteria? There are two principal methods: egalitarian and utilitarian. ${ }^{42}$

Perhaps the best-known example of the egalitarian method is prioritizing by medical need, introduced by Baron Dominique Jean Larrey, Napoleon's Surgeonin-Chief. Prior to the introduction of this method of triage, wounded soldiers were typically left to languish until the battle ended; only then could they hope for medical care, and often by local townspeople. Rather than waiting until it was too late, Larrey began retrieving the wounded for treatment behind the frontlines and systematized the order of treatment to improve the chances of survival. Following the French spirit of equality, he proposed that those most severely wounded be treated first and those with minor injuries later. The revolutionary implication was that medical need trumped military rank, birth, title, or other social status. This egalitarian model of triage has become widely adopted.

The utilitarian model privileges the values and interests of the group over the individual. Influenced by the utilitarian reasoning that dominated British philosophy and ethics in the early nineteenth century, two British physicians developed a method based on the value of the individual to the group. ${ }^{43}$ During World War I the United States adopted a triage method that prioritized those soldiers that could be most quickly returned to combat. ${ }^{44}$ At the current moment health-care workers often get priority because of their value for saving lives; they are also expected to be among the first to receive the Coronavirus vaccine when it becomes available. Unlike with treatment based on need-which can generate reasonably objective criteria - with the utilitarian model groups will often disagree about which values matter

40. Moon and Hoen 2020.

41. See Bollyk and Bown 2020; Kupferschmitt 2020.

42. Baker and Strosberg 1992.

43. Baker and Strosberg 1992, 16. Also see Veatch 2005.

44. Lee 2010, 467. 
most. For instance, aid workers tend to prioritize need but have confronted situations where local populations demand that modestly wounded village elders be treated prior to more severely wounded children because of the former's relative importance. ${ }^{45}$ Because assigning value to a life is inherently subjective, those wanting calculability and more objective indicators for ranking have used likelihood of recovery, expected income generated, and anticipated years of life remaining to determine quality of life. ${ }^{46}$ The elderly and those with pre-existing conditions do not do so well in these rankings.

The egalitarian and utilitarian models usually include an authority, either a trained individual or a small committee, to decide the order. But there is no such authority in global life to determine which states or peoples are most in need or have the most value when distributing scarce resources during emergencies, especially in a world where multiple emergencies occur simultaneously. Under these circumstances charity, mutual aid, and markets become the primary methods of allocation. Charity and humanitarian assistance are perhaps the most famous methods of allocation, especially for vulnerable and marginalized populations in the global South. These affected populations rely on the kindness of strangers, but kindness is usually in short supply relative to demand, especially in pandemics and emergencies. And kindness does not necessarily channel charity to those most in need. Those who give often do so because of perceived need and pre-existing connections and commitments; moral and causality responsibility; guilt, anger, and shame; status seeking; and salvation. Aid agencies routinely try to get people to keep giving by playing the so-called humanity card, circulating graphic images of victims and sad stories about those in need, and preaching that if one can make a life-saving difference without having to sacrifice much, one should. These appeals work on actors with a conscience, which are not states' best feature. States give primarily because of their economic and strategic interests. In response to this inequality, international nongovernmental organizations working with states and international organizations have established various mechanisms to increase the chance that those in need but without powerful friends still get assistance.

In contrast to leaving assistance to unpredictable emotions, there are implicit and explicit contracts of mutual aid based on reciprocity ${ }^{47}$ Principles of mutual aid and diffuse reciprocity operate best when there are pre-existing networks of exchange and attachment, when the aid contract is based on a limited number of actors, and when there is a long shadow of the future. International relations scholars have tested these norms of cooperation under various circumstances, and the norms do not hold up as well in situations where the perceived survival of the actor is at

45. Redfield 2013, 174.

46. See Kelly 2020; Chris Conover, "How Economists Calculate the Costs and Benefits of COVID-19 Lockdown," Forbes, 27 March 2020, retrieved from <https://www.forbes.com/sites/theapothecary/2020/ 03/27/how-economists-calculate-the-costs-and-benefits-of-covid-19-lockdowns/\#5b1bc1916f63>; Hearn 2012.

47. Kropotkin 1902. 
stake, which is, of course, precisely the issue with COVID-19 and the reason that vaccine nationalism appears to be besting various proposals for mutual aid. Evidence of the disintegration of the mutual aid contract came early in the pandemic. The European Union has a convention and emergency bureau to coordinate joint action during disasters. In response to the rapid increase in cases and shortage of medical equipment, Italy called for the bureau's implementation, which included the mandated sharing of national stockpiles and sending doctors to areas with high infection rates and shortages of medical personnel. But every member of the EU refused. ${ }^{48}$

Lastly, markets inform triage practices. Markets might create efficiencies and incentives for producers to shift from making underwear to masks, for example. ${ }^{49}$ But the reliance on markets during emergencies also has complications if the goal is to save as many as possible and preserve a modicum of equity. There is no guarantee that efficiencies will arrive in time to save lives, that producers will shift to public needs, or that life-saving goods will reach those who cannot afford them. A Spencerian survival of the fittest can lead to cutthroat rivalry, outbidding, hoarding, price-gouging, and opportunistic scam artists attempting to sell defective goods at inflated prices. The highest bidder is likely to be the actor with the deepest pockets and the fewest moral scruples. In general, while triage in medical facilities integrates ethics, ethics appears to diminish in prominence as we move away from the hospital and toward the global.

\section{Sacrifice}

Anthropological and religious writings on sacrifice connect the person doing the sacrificing, the thing to be sacrificed, and the broader moral or sacred order. ${ }^{50}$ The sacrifice can serve various functions. It can be a gift-an offering to the heavens for recent fortune, to placate or to honor the Gods, or to solicit protection. ${ }^{51}$ It can communicate gratitude for past and future blessings. It can demonstrate absolute faith in the demands from heavens. Abraham nearly sacrificed his only son Isaac as a sign of his devotion and submission to God. Sacrifices can be part of a process of atonement, repentance, or expatiation for those who have sinned, caused offense, or committed a crime. The crucifixion of Jesus Christ was a sacrifice for our sins. In religious ceremonies those who oversee the sacrifice can be believed to be part of the sacred. Although the discourse of sacrifice has religious overtones, there are secular counterparts. Soldiers are venerated for their sacrifice to the nation, and their sacrifices are often commemorated through monuments, holidays, and other 
rites and rituals that bind the nation. ${ }^{52}$ In this way, most religious and secular sacrifices serve the foundational function of binding the community. The moral order feeds off the dead. ${ }^{53}$

Bradol labelled those innocents who lost their lives in Western-sponsored just wars as sacrifices in relationship to the liberal international order. In other words, the West is doing the sacrificing, the innocents are those being sacrificed, and the recipient of the sacrifice is a sacred liberal international order that aspires to defend humanity and advance moral progress. What about deaths from COVID-19? The connections between the sacrifice, the sacrificed, and the sacred order seem much more tenuous in this case because of ambiguities regarding who is doing the sacrificing and what is the moral order, but this shaky connection returns us to the relationship between COVID-19 and whose lives matter.

Thus far I have claimed that the liberal international order is often treated by those in the West as sacred because of its relationship to humanity and progress. Additionally, I have observed how a market economy that is part of liberalism has been viewed as a source of morality and ethics. ${ }^{54}$ The consequence is that these two moral objects, humanity and the market, are sometimes reinforcing and sometimes incongruent. Liberals venerate humanity and recognize the many sacrifices that have been made in its name. Liberals also treat the market as an important mechanism of progress, and there are times when humans are asked to sacrifice for the economy. As bluntly put by Texas Deputy Governor Dan Patrick, there are more important things than living, and those include saving the economy. ${ }^{55}$ And while humanity and market can go hand-in-hand-as when markets are viewed as important to human well-being and progress - there are other times when humanity and markets appear to operate at cross-purposes. At the outset of the pandemic, lives were seen as taking precedence over the needs of the economy. But how long would that be allowed to continue? Writing in early May when government and health officials still agreed on using lockdown measures to flatten the curve, three scholars predicted: "As the 'sufferings' of capital intensify in the current crisis, we can expect a shift in crisis policy toward a more open assertion that if the biopolitical interests of capital and those of human life increasingly clash, the interests of capital 'must' be given precedence." 56

My selectively scattered and completely unscientific reading of how deaths from COVID-19 are framed suggests that the language of sacrifice comes more naturally when it is connected to humanity than when it is connected to the market, but the market is not without a flock. The language of sacrifice is most prevalent when

52. Marvin and Ingle 1996.

53. Hedley 2011, 262.

54. See Brown 2015; Harvey 2005; Block and Somers 2014, 3.

55. Patrick Samuels, "Dan Patrick says that 'There are More Important Things Than Living and That's Saving the Country," Texas Tribune, 21 April 2020, retrieved from <https://www.texastribune.org/2020/ 04/21/texas-dan-patrick-economy-coronavirus/>.

56. Hannah, Hutta, and Schemann 2020. 
referring to the deaths of those who caught COVID-19 and died as a result of trying to save the lives of others. These are medical personnel, health-care workers, and care givers. ${ }^{57}$ They were not sacrificed but rather acted in the quasi-religious spirit of self-sacrifice. And they gave their lives for the belief that all lives are equal and are equally deserving of care. Health workers are singled out for their courage and humanity, and called saintly by their loved ones and others who worked alongside them. In this respect, they bear considerable resemblance to aid workers who have died while providing relief during humanitarian emergencies. And like aid workers, those treating victims of COVID-19 are often seen as waging their battle on a frontline. A future indicator that health workers who died in the line of duty have obtained the status of sacrifices is if memorials are erected to consecrate their service in the name of humanity.

The language of sacrifice is used less frequently in connection to essential workers. Bus drivers, those working in slaughterhouses, UPS delivery persons, Instacart employees filling orders at Whole Foods for wealthy families, and teachers mandated to return to the classroom are risking their lives for others, but rarely described as a sacrifice in relationship to a moral order. Why not? Among the possibilities, two stand out. One is that the term "essential workers" is too broad because it potentially includes those taking risks so that others do not, and also those whose status as "essential" seems much more debatable. For instance, do we want to equate the pharmacist with the person working at a gun shop or a liquor store that is deemed essential by the local or state government? A second possibility is that sacrifice should be reserved for those who enact a calling that connects to the sacred. Medical personnel are assumed to qualify, but what about those who perform essential services because they need to earn a paycheck? They appear to be operating in the realm of the profane and not the sacred. It is entirely understandable that they would put themselves at risk - they need a job to put food on the table, to keep their home, and to afford medical care. But those who work for a living rather than a calling are rarely labeled as sacrifices, and their deaths are rarely mourned in the same way.

There is another category of death that might be more appropriate for those who die from COVID-19 after being compelled or forced to put themselves at risk: "those who can be killed." Agamben created this category in his discussion of homo sacer. ${ }^{58}$ Homo sacer derives from Roman law and is a person who has been judged to have committed a crime. Although he cannot be sacrificed, he can be killed, and his killer cannot be charged with homicide. The sovereign is the one who can decide to give and take away life, and the one who can use the law to exclude the person from the protection of law. Although essential workers and those who have no viable alternative to returning to a risky workplace have committed no crime, they resemble those who can be killed. They are often individuals who are compelled to take high-risk jobs because of the money-those at or below 
the poverty line-or because of state mandates, as with teachers. In both cases, though, the state could alleviate this pressure. For those who are economically vulnerable, the government could provide more relief, extended unemployment benefits, food stamps, health coverage, and other supports. But this would hold back the economy and require a rise in deficit spending. For teachers, the state could permit online learning, which would make it more difficult for parents to go back to work. In order to protect public and private institutions from lawsuits from an employee or user of a public or private facility who contracts COVID-19, some states are introducing liability laws that minimize damages or give immunity. If institutions do not receive this protection, the argument goes, then they will be unable to open because of the risk of litigation if someone gets sick or dies. But what if these institutions do not take basic precautions to protect their workers? Does this mean that the state has sanctioned their death by COVID-19? Do those teachers and professors who have been forced to go back into the classroom count as "those who can be killed"?

Are there other categories of the dead? There are regrettable deaths: those who died despite valiant efforts. There are needless deaths: those who died above and beyond the numbers that might have occurred had reasonable precautions and actions been taken by the state. There are also the abandoned: those who have been left to die because the state has put them aside and given up on them, resembling triage. ${ }^{59}$ And then there are the unseen: those whose lives are not even recognized and whose deaths are not grievable. Some of them reside in the liberal order, but many are outside of it or on its borders. They are refugees, displaced, and migrants, those from lower castes in places such as India, and millions more marginalized and vulnerable people. In terms of the hierarchy of humanity, they are on the bottom rung. According to Richard Rorty, these people become "dead to us." 60

\section{Conclusion}

All international orders demand their sacrifices. Coming from the medical relief sector, Bradol adopted a broad notion of sacrifice that included needless and preventable deaths. Religious and anthropological discussions of sacrifice, however, are more circumscribed and premised on a connection between the dead and the moral order. In other words, there are many needless and preventable deaths, but only a sanctified few obtain the status of sacrifice. Although all international orders have their sacrificial element, they can potentially be distinguished by the basis used to select the sacrifices and the meanings invested in them. The sacrificial elements can be hidden from view during settled times, but during unsettled times they emerge out of the mist and into view. COVID-19 is most definitely an unsettled 
period, and as with all humanitarian emergencies, the hierarchy of humanity and who is saved and who dies become the focus of attention.

The liberal international order is comprised of various principles and parts, though I have focused on the relationship between humanity and the market. Both are central to the liberal international order, and their relationship can be mutually beneficial, constraining, or constituting. Beginning with the enlightenment and the establishment of liberalism, moral progress defined by humanity and a marketdriven material progress have often been viewed as mutually beneficial. Guided by a humanitarian governance that held that saving lives and reducing suffering make up the highest moral principle, states and societies increasingly became organized around human betterment. The state and society developed various humanitarian institutions that were designed to help the worst-off, but in the long run it would be an expanding market economy and not charity that would generate peace, prosperity, and progress.

But COVID-19 provides a window into a much more complicated relationship between morality and markets. Despite the claim of equality, liberalism contains a hierarchy of humanity, which is particularly evident in situations when lives are at stake. The market profoundly shapes who gets access to life-saving resources, who benefits from making live, and who suffers from letting die. The concept of the moral economy focuses attention on just these considerations, especially during periods of extreme hardship, economic crises, and pandemics when life-saving resources are scarce and states often make life-and-death decisions regarding who will live and die. The moral economy is not just national but also global. The global method of triage tends to be neither egalitarian nor utilitarian but rather market-driven, which reinforces a moral economy in which those who are last in line for access to necessary resources are the first in line for death. Such ordering is not random but rather an effect of historically-produced and structurally-induced preconditions that leave some groups more vulnerable than others. Some of the dead will be counted as sacrifices, but arguably many more on the death registry will be listed as unseen, abandoned, and permitted to be killed. Most of them will end up in a Potter's Field.

The liberal international order has a difficult time recognizing its dead. This is an order that is built around the belief in humanity and progress, in which all lives are equal and deserving of equal care and shared duties and responsibilities exist to alleviate unnecessary pain and suffering. To what extent does the discipline of international relations resemble the theory and practice of the liberal international order? How much attention is there to the hierarchy of humanity and the process of giving life and letting die? Does the discipline have the theories and the ethics to account for those who occupy the lesser rungs? Is it capable of making connections between those at the top and those at the bottom? COVID-19 challenges not just the current international order but how the discipline chooses to conceptualize international order. What would the discipline look like if the concept of sacrifice became an organizing principle? Would it be much more likely to follow Foucault's 
guidance that "the misfortunes of men must never be the silent leftover of politics"? ${ }^{61}$

\section{References}

Adelman, Jeremy. 2020. Introduction: The Moral Economy, The Careers of a Concept. Humanity 11 (2):187-92. Agamben, Gorgio. 1998. Homo Sacer: Sovereign Power and Bare Life. Stanford University Press. Arendt, Hannah. 1963. On Revolution. Penguin Books. Arnold, Thomas. 2001. Rethinking Moral Economy. American Political Science Review 95 (1):85-95. Baker, R., and M. Strossberg. 1992. Triage and Equality: An Historical Assessment of Utilitarianism Analyses of Triage. Kennedy Institute of Ethics Journal 2 (2):103-23.

Bethencourt, Francisco. 2016. Humankind: From Division to Recomposition. In Humanity: A History of European Concepts in Practice from the Sixteenth Century to the Present, edited by F. Klose and Mirjam Thulin, 29-50. Vandenhoeck \& Ruprecht.

Biehl, Joao. 2005. Vita: Life in a Zone of Abandonment. University of California Press

Block, Fred, and Margaret Somers. 2014. The Power of Market Fundamentalism: Karl Polanyi's Critique. Harvard University Press.

Bollyky, Thomas, and Chad Brown. 2020. The Tragedy of Vaccine Nationalism: Only Cooperation can End the Pandemic. Foreign Affairs 99 (5):96-109.

Bradol, Jean Hervé. 2004. Introduction: The Sacrificial International Order and Humanitarian Action. In The Shadow of 'Just Wars': Violence, Politics and Humanitarian Action, edited by F. Weissman, 1-22. Cornell University Press.

Brown, Wendy. 2015. Undoing the Demos: Neoliberalism's Stealth Revolution. Zone Books.

Chrostowski, Waldemar. 1991. The Suffering, Chosenness and Mission of the Polish Nation. Occasional Papers on Religion in Eastern Europe 11 (4). Retrieved from <https://digitalcommons.georgefox.edu/ cgi/viewcontent.cgi?article=1601\&context=ree>. Accessed 2 September 2020.

Cladis, Mark. 2008. Introduction to Elementary Forms of Religious Life, by Emile Durkheim, vii-xli. Oxford University Press.

Clover, Joshua. 2020. "The Rise and Fall of Biopolitics: A Response to Bruno Latour," In the Moment (blog). 29 March. Retrieved from <https://critinq.wordpress.com/2020/03/29/the-rise-and-fall-of-biopolitics-a-response-to-bruno-latour/>. Accessed 17 September 2020.

Coetzee, J.M. 1985. Life and Times of Michael K. Penguin.

Davies, William. 2016. The New Neoliberalism. New Left Review 101:121-34.

Davis, Mike. 2020a. "Who Gets Forgotten in a Pandemic?" The Nation. 13 March. Retrieved from <https:// www.thenation.com/article/politics/mike-davis-covid-19-essay/>. Accessed 17 September 2020.

Davis, Mike 2020b. The Monster Enters. New Left Review 122:7-14.

Dubois, W.E.B. 1925. Worlds of Color. Foreign Affairs 3 (3): 423-44.

Farmer, Paul. 2004. An Anthropology of Structural Violence. Current Anthropology 45 (3):305-25.

Fassin, Didier. 2007. Humanitarianism as a Politics of Life. Public Culture, 19 (3):199-520.

Fassin, Didier. 2011. Humanitarian Reason: A Moral History of the Present. University of California Press.

Fassin, Didier. 2020a. "An Unprecedented Health Crisis: Didier Fassin on the Global Response to the Covid Pandemic." Institute for Advanced Study. 3 June. Retrieved from <https://www.ias.edu/ideas/ fassin-covid-global-response>. Accessed 17 September 2020.

Fassin, Didier. 2020b. Are the Two Approaches to Moral Economy Irreconcilable? Humanity: 11 (2): $217-21$.

61. Foucault 1994, 708; quoted in Finkielkraut 2000, 88. 
Festa, Lynn. 2010. Humanity Without Feathers. Humanity 1 (1):3-27.

Fiering, Norman. 1976. Irresistible Compassion: An Aspect of Eighteenth Century Sympathy and Humanitarianism. Journal of the History of Ideas 37 (2):195-218.

Finkielkraut, Alain. 2000. In the Name of Humanity: Reflections on the Twentieth Century. Columbia University Press.

Foucault, Michel. 1994. Dits et Écritis, Vol. 4. Gallimard.

Foucault, Michel. 1995. Discipline and Punish: The Birth of the Prison. Translated by Alan Sheridan. Vintage Books.

Foucault, Michel. 2003. Society Must Be Defended: Lectures at the Collège de France (Book 5). Picador. Fourcade, Marion, and Kieran Healy. 2007. Moral Views of Market Society. Annual Review of Sociology 33:285-311.

Fouskas, Vassilis and Bulent Gokay, 2020. "COVID-19 and the Bankruptcy of Neoliberalism in the context of Global Shift," openDemocracy. 5 May. Retrieved from <https://www.opendemocracy.net/ en/author/vassilis-k-fouskas/>. Accessed 12 June 2020.

Galtung, Johan. 1969. Violence, Peace, and Peace Research. Journal of Peace Research 8 (2):81-117.

Global Witness. 2020. "COVID-19 Tracing Apps Must Not Interfere with Human Rights." 14 May.

Retrieved from <https://www.globalwitness.org/en/campaigns/covid-19-tracing-apps-must-not-interfere-human-rights/>. Accessed 15 August 2020.

Hannah, Matthew, Jan Hutta, and Christoph Schemann. 2020. "Thinking Through COVID-19 Responses with Foucault," Antipode, 5 May. Retrieved from <https://antipodeonline.org/2020/05/05/thinkingthrough-covid-19-responses-with-foucault/>. Accessed 17 September 2020.

Hark, Sabine. 2020. "Corona and the Moral Economy of Life." Critical Times. 23 June. Retrieved from $<$ https://ctjournal.org/2020/06/23/corona-and-the-moral-economy-of-life/>. Accessed 17 September 2020.

Harvey, David. 2005. A Brief History of Neoliberalism. Oxford University Press.

Hearn, James. 2012. Social Utility and Pandemic Influenza Triage. Medicine and Law 32(2):177-90.

Hedley, Douglas. 2011. Sacrifice, Transcendence, and 'Making Sacred'. Royal Institute of Philosophy Supplement 68:257-68.

Hubert, Henri, and Marcel Mauss. 1981. Sacrifice: Its Nature and Functions. University of Chicago Press.

Ingram, Alan. 2020. Critical Approaches to Global Health. In The Oxford Handbook of Global Health Politics, edited by C. McInnes, K. Lee, and J. Youde, 85-102. NY: Oxford University Press.

International Federation of the Red Cross and Red Crescent. "The Fundamental Principles of the Red Cross." Geneva. Retrieved from <http://www.ifrc.org/en/who-we-are/vision-and-mission/the-sevenfundamental-principles/humanity/>. Accessed 17 January 2016.

Kamen, Henry. 2014. The Spanish Inquisition: A Historical Revision. Yale University Press.

Kelly, Peter. 2020. "What is a Death Worth? A Life? The Moral Economy of COVID-19." Retrieved from $<$ https://youngpeopleanthropocene.org/2020/06/19/what-is-a-death-worth-a-life-the-moral-economy-ofcovid-19/>. Accessed 17 September 2020.

Kleinman, A., V. Das, and M. Lock, eds. 1997. Social Suffering. University of California.

Kropotkin, Peter. 1902. Mutual Aid: A Factor of Evolution. Retrieved from <https://www.marxists.org/ reference/archive/kropotkin-peter/1902/mutual-aid/index.htm>. Accessed 11 June 2020.

Kupferschmitt, Kai. 2020. “'Vaccine Nationalism' Threatens Global Plan to Distribute COVID-19 Shots Fairly," Science, American Academy of Arts and Science. 28 July. Retrieved from <https://www. sciencemag.org/news/2020/07/vaccine-nationalism-threatens-global-plan-distribute-covid-19-shots-fairly>. Accessed 13 August 2020.

Lee, Christopher. 2010. Disaster and Mass Casualty Triage. American Medical Association Journal of Ethics 12 (6):466-70.

Lorenzini, Daniele. "Biopolitics in the Time of Coronavirus," In the Moment (blog), 2 April. Retrieved from <https://critinq.wordpress.com/2020/04/02/biopolitics-in-the-time-of-coronavirus/>. Accessed 28 May 2020.

Marvin, Carolyn and David Ingle. 1996. Blood Sacrifice and the Nation: Revisiting Civil Religion. Journal of the American Academy of Religion 64 (4):767-80. 
Michéa, Jean-Claude. 2009. The Realm of the Lesser Evil. Polity Press.

Moon, Suerie, and Ellent Hoen. 2020. The Global Politics of Access to Medicines. In The Oxford Handbook of Global Health Politics, edited by C. McInnes, K. Lee, and J. Youde, 605-27. Oxford University Press.

Nava, Stefano, Roberto Tollini, and Enrico Clini 2020. An Italian Sacrifice to the COVID-19 Epidemic. European Respiratory Journal, 55. Retrieved from <https:/erj.ersjournals.com/content/55/6/ 2001445>. Accessed 17 September 2020.

Pictet, Jean. 1979. The Fundamental Principles of the Red Cross. International Review of the Red Cross 19 (210):130-49.

Polanyi, Karl. 2001. The Great Transformation. Beacon Press.

Redfield, Peter. 2013. Life in Crisis: The Ethical Journey of Doctors Without Borders. University of California Press.

Rorty, Richard. 1996. Who are We? Moral Universalism and Economic Triage. Diogenes 44 (1):5-15.

Rowden, Rick. 2009. The Deadly Ideas of Neoliberalism: How IMF has Undermined Public Health and the Fight Against AIDS. Zed Books.

Ruckert, Arne, and Ronald Lebonté. 2013. The Financial Crisis and Global Health: The IMF's Policy Response. Health Promotion International 28 (3):357-66.

Ruggie, John. 1982. International Regimes, Transactions, and Change: Embedded Liberalism in the Postwar Economic Order. International Organization 36 (2):379-415.

Sandberg, Joakim. 2015. Moral Economy and Normative Ethics. Journal of Global Ethics 11 (2):176-87.

Schrecker, Ted. 2020. Toward a Critical Political Economy of Global Health. In The Oxford Handbook of Global Health Politics, edited by C. McInnes, K. Lee, and J. Youde, 469-90. Oxford University Press.

Scott, James. 1976. The Moral Economy of the Peasant: Rebellion and Subsistence in South East Asia. Yale University Press.

Scott, James. 2005. Afterword to 'Moral Economies, State Spaces, and Categorical Violence,' American Anthropologist 107 (3):395-402.

Sharma, Sanjay. 2001. Famine Philanthropy and the Colonial State: North India in the Early Nineteenth Century. Oxford University Press.

Slobodian, Quinn. 2018. The Globalists: The End of Empire and the Birth of Neoliberalism. Harvard University Press.

Stuurman, Siep. 2017. Invention of Humanity. Harvard University Press.

Sznaider, Natan. 1998. The Sociology of Compassion: A Study in the Sociology of Morals. Cultural Values, 2 (1):117-39.

Thompson, E.P. 1971. The Moral Economy of the English Crowd in the Eighteenth Century. Past and Present 50:76-136.

Thompson, E.P. 1991. The Moral Economy Reviewed, in Customs in Common, 259-351. Merlin.

Trouiller P., P. Olliaro, E. Torreele, J. Orbinski, R. Laing, and N. Ford. 2002. Drug Development for Neglected Diseases: A Deficient Market and a Public-Health Policy Failure. Lancet 359 (9324): $2188-2194$.

Veatch, Robert. 2005. Disaster Preparedness and Triage: Justice and the Common Good. Mount Sinai Journal of Medicine 72 (4):236-41.

Wilson, Richard Ashby, and Richard Brown 2009. Introduction. In Humanitarianism and Suffering: The Mobilization of Empathy, edited by R. Wilson and R. Brown, 1-31. Cambridge University Press.

\section{Authors}

Michael Barnett is University Professor of International Affairs and Political Science at the George Washington University. He can be reached at barnett@gwu.edu. 


\section{Acknowledgments}

I would like to thank the editors for providing the opportunity to write this essay and for their excellent comments. In addition to the comments provided by those on the Zoom meetings, I want to thank Tanisha Fazal, Bud Duvall, Antonio Donini, Miriam Ticktin, Ilana Feldman, Unni Karunakara, and Peter Redfield.

\section{Key Words}

COVID-19; Liberal International Order; Sacrificial International Order; moral economy; humanitarian governance; triage; sacrifice; international relations theory 